\title{
Prolactin regulation of testosterone secretion and testes growth in DLS rams at the onset of seasonal testicular recrudescence
}

\author{
L M Sanford and S J Baker \\ Department of Animal Science, McGill University, Macdonald Campus, Ste Anne de Bellevue, Québec, \\ Canada H9X 3V9 \\ Correspondence should be addressed to L M Sanford who is now at 111 Bruce Street, Suite 616, Kirkland, Québec, \\ Canada H9H 4B7; Email: Isanford@total.net
}

\begin{abstract}
Our objective was to test the hypothesis that prolactin (PRL) acts at both the pituitary and testis levels to regulate testosterone secretion in the adult ram. The focus was on the mid-regression to mid-redevelopment stages of a photoperiod-condensed 'seasonal' testicular cycle. DLS rams (six per group) were given daily s.c. injections of bromocriptine $(4 \mathbf{~ m g})$ or vehicle during the entire period. Serum PRL concentration in control rams peaked at $103.4 \pm 22.1 \mathrm{ng} / \mathrm{ml}$ in late regression and then steadily declined $(P<0.01)$ to $19.5 \pm 4.3 \mathrm{ng} / \mathrm{ml}$, whereas PRL in treated rams was always $\leq 4.0 \mathrm{ng} / \mathrm{ml}$. Suppression of PRL tended $(P<0.10)$ to increase the amplitude of natural $\mathrm{LH}$ pulses (transition stages) or reduce the number of LH receptors in the testis (regressed stage), although neither change disturbed testosterone levels in peripheral blood. These subtle changes were accompanied by significant $(\boldsymbol{P}<0.05)$ alterations in the capability of the pituitary to release $\mathrm{LH}(\mathbf{8 5} \%$ more) and of the testes to secrete testosterone $(20 \%$ less). These effects of PRL were unmasked when rams were given highly stimulative i.v. injections of GNRH (single $3 \mu \mathrm{g}$ dose) and NIH-oLH-S24 (three $5 \mu \mathrm{g}$ doses given 20 min apart) respectively. PRL insufficiency also appeared to slow down the 'seasonal' rise in FSH secretion and slightly delayed ( 2 weeks) the times when the testes began to grow and were first significantly $(P<0.05)$ enlarged from the regressed state. We conclude that PRL is an important part of the intricate regulation of the pituitary-gonadal system in moderately seasonal DLS rams.

Reproduction (2010) 139 197-207
\end{abstract}

\section{Introduction}

Prolactin (PRL) is a polypeptide hormone that is synthesized and secreted mainly by lactotrophs in the anterior pituitary gland. It has numerous actions in mammalian biological systems (Bole-Feysot et al. 1998, Freeman et al. 2000), including the reproductive processes of species that breed seasonally such as golden hamsters and black bears (spring), and sheep and deer (autumn) (Curlewis 1992, Bartke 2004). Sheep exhibit a robust annual cycle in PRL secretion that is closely related to day length. Blood PRL concentrations in rams are highest near the summer solstice and lowest near the winter solstice, times that fall within the developing and regressing stages of the seasonal testicular cycle respectively (Lincoln 1990, Lincoln et al. 1990). PRL seems to act at several levels of the reproductive axis in rams. Receptors for PRL have been located in neuronal cell bodies in areas of the ovine hypothalamus involved in regulating GNRH secretion (Tortonese et al. 1996) and in pituitary gonadotrophs (Tortonese et al. 1998). Germ cells undergoing spermatogenesis and Leydig cells also possess PRL receptors (Jabbour \& Lincoln 1999). Thus, PRL has the means to participate both directly and indirectly in the regulation of gonadal function.

Several studies indicate that PRL functions as a gonadotropic hormone in the ram. Suppression of PRL secretion with bromocriptine in the spring may reduce the size of the regressed testes (Regisford \& Katz 1993), delay the onset of testicular recrudescence (Barenton \& Pelletier 1980) or slow down the growth of the testes during recrudescence (Sanford \& Dickson 2008). In the last instance there was also a temporary decrease in sperm output and a delay in the time of peak testis size in the summer. These anomalies were not caused by inadequate secretion of $\mathrm{FSH}$ or testosterone, the two key regulators of spermatogenesis in the ram (Courot \& Ortavant 1981, Kilgour et al. 1994). Inducing hypoprolactinemia in rams has also been shown to diminish testosterone secretion by the developing (Lincoln et al. 2001, Sanford \& Dickson 2008) and redeveloped (Regisford \& Katz 1993) testes. In most cases, lower testosterone output cannot be explained simply, if at all, by a reduction in the strength of the circulatory $\mathrm{LH}$ signal. PRL could influence testosterone biosynthesis in rams by altering the sensitivity of Leydig cells to $\mathrm{LH}$ 
(i.e. the number of $\mathrm{LH}$ receptors on the cell surface; Regisford \& Katz 1994).

Unlike in the rat (Voogt et al. 1987, Koike et al. 1991), PRL treatment does not appear to suppress hypothalamic GNRH secretion in sheep. Infusion of PRL into the third ventricle of the brain has little or no effect on episodic LH release in either rams (Lincoln \& Tortonese 1997, Romanowicz et al. 2004) or ewes (Curlewis \& McNeilly 1991, Misztal et al. 2005). Furthermore, maintaining blood PRL at high (long day) concentrations in rams during testicular reactivation slightly elevates mean LH and FSH concentrations (Lincoln \& Tortonese 1999). Conversely, inhibiting the spring rise in PRL secretion can result in unusually slow seasonal increases in FSH secretion and $\mathrm{LH}$ pulse amplitude and frequency (Sanford \& Dickson 2008). Thus, PRL seems to facilitate rather than hinder the central activation of gonadotropin secretion in rams. Relatively little is known about whether PRL influences $\mathrm{LH}$ and FSH secretion in sheep by acting on the pituitary. In a study with ovine pituitary cell cultures, PRL (in the presence of dopamine) was shown to block the $\mathrm{LH}$ response to GNRH stimulation when cells were collected in the summer, but not in the winter (Gregory et al. 2004).

The present investigation was designed to test the hypothesis that PRL acts at both the pituitary and testis levels to regulate testosterone secretion in the adult ram. The focus was on the mid-regression to mid-redevelopment stages of a photoperiod-condensed 'seasonal' testicular cycle. Our first aim was to determine whether $\mathrm{PRL}$ promotes the expression of $\mathrm{LH}$ receptors, as it does in several rodent species (Bartke 2004), thereby enhancing the response of Leydig cells to LH stimulation when the testes are regressed and (or) beginning to redevelop. The role of endogenous PRL in modulating $\mathrm{LH}$ receptors has been evaluated only when the testes are well developed (Barenton et al. 1982, Regisford \& Katz 1994) and not during the crucial period of testicular activation. Our second aim was to determine if PRL attenuates the amplitude of $\mathrm{LH}$ pulses, thus providing a negative control of testosterone secretion. PRL impairs the in vitro $\mathrm{LH}$ response of the pituitary to GNRH stimulation in the rat (Cheung 1983) and may do so in sheep (Gregory et al. 2004). Whether PRL directly or indirectly (via FSH and testosterone) affects testis growth in moderately seasonal rams was also of interest.

\section{Results}

\section{Testicular size and blood PRL concentration}

The photoperiod regimen imposed on the rams induced predictable changes in testis size (Fig. 1B). During the initial period (adaptation) of short days, estimated testes mass increased $(P<0.01)$ from $286 \pm 15 \mathrm{~g}$ to a maximum of $385 \pm 17 \mathrm{~g}$ and then returned $(P<0.01)$ to $285 \pm 14 \mathrm{~g}$. During the subsequent period (experimental) of long
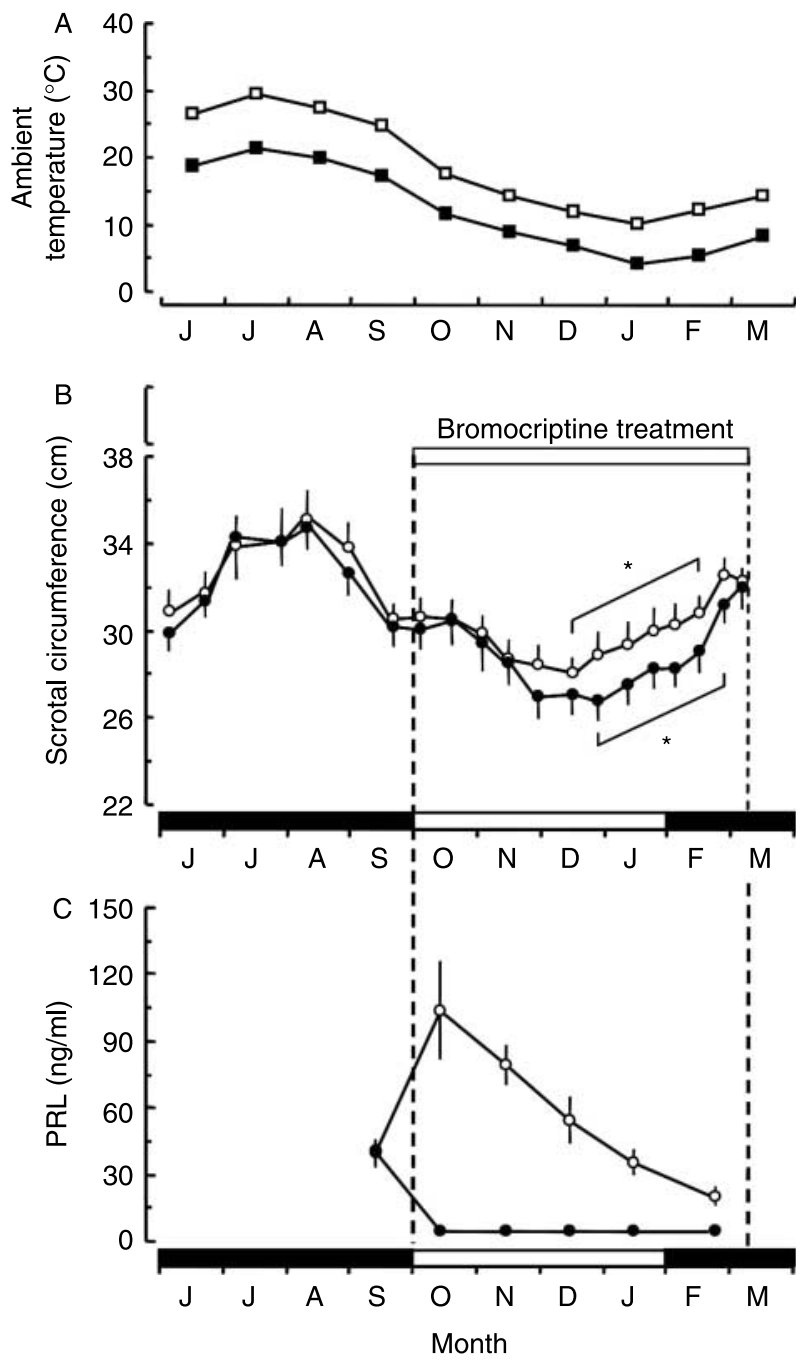

Figure 1 (A) Mean monthly ambient temperatures (highs $\square$, lows in the light-controlled rooms, and (B) scrotal circumference, and $(C)$ serum prolactin concentration for control rams $(O)$ and bromocriptine-treated rams ( ). Daily injections of bromocriptine (4 mg s.c.) or vehicle began at the onset of 4 months of long days (16 h light: $8 \mathrm{~h}$ darkness, $\square x$-axis) and ended after 5 weeks of short days ( $8 \mathrm{~h}$ light:16 $\mathrm{h}$ darkness, $\mathbf{x}$-axis). Data are means \pm s.e.m. $(n=6$ rams). ${ }^{*}$ Indicates a significant $(P<0.05)$ change in time within group.

and short days, the testes mass decreased $(P<0.01)$ further to a minimum of $224 \pm 13 \mathrm{~g}$ and then increased $(P<0.01)$ to $323 \pm 12 \mathrm{~g}$. The testes of both control and bromocriptine-treated rams were clearly in transition stages in the first month of long (regressing) and short (developing) days, and were considered to be either in or emerging from the regressed stage during the last 2 months of long days.

The total loss in testes mass during regression was similar for the control $(41 \pm 2 \%)$ and treated $(45 \pm 4 \%)$ rams, although testis size decreased more abruptly in the treated rams at the end of this stage. Re-growth of the testes was delayed by 2 weeks in the treated rams and thus their testes were somewhat smaller $(\sim 15 \%)$ than 
usual late in long days. The time in short days when the testes were first significantly $(P<0.05)$ enlarged from the regressed state was also later for the treated rams (week 4) than the controls (week 2). Testes grew at the same rate in control $(6.6 \pm 0.6 \mathrm{~g} /$ week $)$ and treated $(5.8 \pm 1.6 \mathrm{~g} /$ week) rams in long days, but at a faster rate $(P<0.05)$ in the treated rams $(18.8 \pm 2.2$ vs 9.8 $\pm 2.7 \mathrm{~g}$ (week) in short days.

Serum PRL concentration was similar in both groups of rams prior to the start of bromocriptine treatment (Fig. 1C). In the controls, PRL concentration increased $(P<0.01)$ from $40.6 \pm 2.7 \mathrm{ng} / \mathrm{ml}$ to a high of 103.4 $\pm 22.1 \mathrm{ng} / \mathrm{ml}$ in the first month of long days and then steadily declined $(P<0.01)$ to $19.5 \pm 4.3 \mathrm{ng} / \mathrm{ml}$ during the ensuing months. Bromocriptine effectively suppressed PRL concentration in the treated rams from $39.9 \pm 6.3 \mathrm{ng} / \mathrm{ml}$ prior to injection to $4.0 \mathrm{ng} / \mathrm{ml}$ or less throughout the experimental period.

\section{Blood testosterone, $\mathrm{LH}$ and FSH concentrations}

Serum concentrations of testosterone (Fig. $2 \mathrm{~A}$ ) and $\mathrm{LH}$ (Fig. 2B) gradually increased $(P<0.05)$ in a similar fashion in control and bromocriptine-treated rams under long days. Serum FSH concentration (Fig. 2C) increased in the last 2 months of long days, but more so in the control rams $(27.7 \pm 2.8-66.0 \pm 9.8 \mathrm{ng} / \mathrm{ml}, P<0.01)$ than in the treated rams $(29.2 \pm 2.9-41.1 \pm 2.2 \mathrm{ng} / \mathrm{ml})$. Consequently, FSH was slightly lower $(P<0.10)$ in the treated rams during these 2 months. Mean concentration of all three hormones abruptly increased $(P<0.05)$ in both groups of rams after photoperiod changed to short days.

\section{Episodic $\mathbf{L H}$ and testosterone secretion}

The amplitude of $\mathrm{LH}$ pulses in the control rams increased $(P<0.05)$ progressively under long days and remained high in short days (Table 1). LH pulse frequency did not change during long days, but soon doubled $(P<0.05)$ in short days. LH pulsatility differed to an extent in the bromocriptine-treated rams in that pulse amplitude tended to be greater $(P<0.10)$ in these rams than the controls in the first month of long days and in short days. Basal (interpulse) LH concentration steadily increased $(P<0.01)$ in all rams after the second month of long days.

Suppression of PRL secretion did not affect any of the parameters of episodic testosterone secretion in either long or short days (Table 1). For rams generally, testosterone pulse frequency and basal (interpulse) concentration increased $(P<0.01)$ slowly during long days and then more dramatically in short days. Testosterone pulse amplitude did not change under long days, but was greater $(P<0.01)$ after rams were exposed to the month of short days.
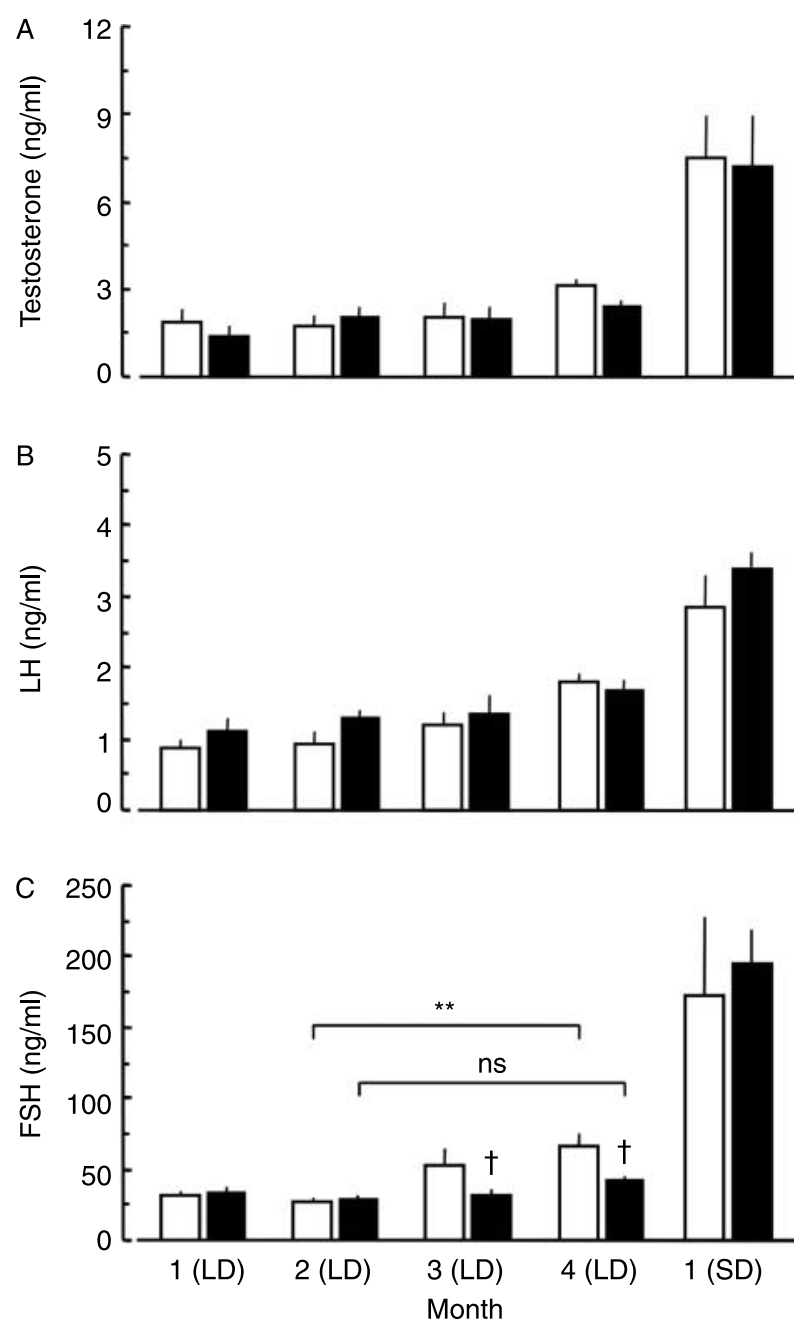

Figure 2 Serum concentrations of (A) testosterone, (B) LH, and (C) FSH for control rams $(\square)$ and bromocriptine-treated (4 mg/day s.c.) rams (ם). Rams were kept under 4 months of long days ( $16 \mathrm{~h}$ light: $8 \mathrm{~h}$ darkness, LD) followed by 1 month of short days ( $8 \mathrm{~h}$ light: $16 \mathrm{~h}$ darkness, SD). Data are means \pm s.E.M. ( $n=6$ rams). ${ }^{* *}$ Indicate a significant $(P<0.01)$ change in time within group, and ${ }^{+}$indicates a subtle difference $(P<0.10)$ between groups. ns signifies nonsignificance $(P>0.10)$.

\section{$L H$ and $F S H$ responses to $G N R H$ injection}

GNRH treatment (single $3 \mu$ g dose) provoked a rapid increase in serum $\mathrm{LH}$ concentration that consistently peaked at 20 min (Fig. 3A). Neither LH peak amplitude nor the total $3 \mathrm{~h}$ LH response (Fig. 3B) changed in the control rams during the experimental period. The amplitude of the $\mathrm{LH}$ peak $(\sim 16 \mathrm{ng} / \mathrm{ml})$ was about 2.5 -fold greater than the amplitude of the largest of the episodic $\mathrm{LH}$ releases $(\sim 6 \mathrm{ng} / \mathrm{ml})$ that occurred when the testes were growing. The $\mathrm{LH}$ response to the $\mathrm{GNRH}$ challenge was nearly twice as great (both parameters, $P<0.05)$ in the bromocriptine-treated rams as in the control rams in the first and last months of long days and in the month of short days. The associated FSH response 
Table 1 Serum parameters of episodic LH and testosterone secretion in control and bromocriptine-treated (4 mg/day s.c.) rams.

\begin{tabular}{|c|c|c|c|c|c|c|}
\hline \multirow[b]{2}{*}{ Hormonal parameter ${ }^{b}$} & \multirow[b]{2}{*}{ Group } & \multicolumn{5}{|c|}{ Month $^{\mathrm{a}}$} \\
\hline & & $1(\mathrm{LD})$ & $2(\mathrm{LD})$ & 3 (LD) & $4(\mathrm{LD})$ & $1(\mathrm{SD})$ \\
\hline \multicolumn{7}{|l|}{ LH } \\
\hline \multirow[t]{2}{*}{ Pulse amplitude (ng/ml) } & Control & $1.11 \pm 0.23(5)$ & $1.64 \pm 0.43(4)$ & $2.80 \pm 0.67(5)$ & $3.42 \pm 0.52$ & $3.85 \pm 0.99$ \\
\hline & Treated & $3.02 \pm 1.28(4)^{*}$ & $3.34 \pm 0.74(5)$ & $2.12 \pm 0.62(4)$ & $3.09 \pm 0.46$ & $5.72 \pm 0.83^{*}$ \\
\hline \multirow[t]{2}{*}{ Pulse frequency (no per $6 \mathrm{~h}$ ) } & Control & $1.3 \pm 0.4$ & $1.0 \pm 0.4$ & $1.0 \pm 0.3$ & $1.7 \pm 0.2$ & $3.0 \pm 0.3$ \\
\hline & Treated & $0.8 \pm 0.3$ & $1.2 \pm 0.3$ & $1.5 \pm 0.7$ & $1.3 \pm 0.2$ & $2.7 \pm 0.3$ \\
\hline \multirow[t]{2}{*}{ Basal concentration (ng/ml) } & Control & $0.63 \pm 0.07$ & $0.67 \pm 0.08$ & $0.81 \pm 0.10$ & $1.04 \pm 0.07$ & $1.53 \pm 0.08$ \\
\hline & Treated & $0.72 \pm 0.06$ & $0.76 \pm 0.04$ & $0.91 \pm 0.13$ & $1.06 \pm 0.12$ & $1.78 \pm 0.19$ \\
\hline \multicolumn{7}{|l|}{ Testosterone } \\
\hline \multirow[t]{2}{*}{ Pulse amplitude (ng/ml) } & Control & $5.41 \pm 1.89(5)$ & $5.54 \pm 0.92$ & $5.40 \pm 1.25$ & $4.71 \pm 0.32$ & $8.90 \pm 1.73$ \\
\hline & Treated & $5.33 \pm 1.18(5)$ & $4.66 \pm 0.97$ & $3.68 \pm 1.07(5)$ & $4.24 \pm 0.67$ & $8.74 \pm 2.12$ \\
\hline \multirow[t]{2}{*}{ Pulse frequency (no per $6 \mathrm{~h}$ ) } & Control & $1.0 \pm 0.3$ & $1.2 \pm 0.3$ & $1.3 \pm 0.2$ & $2.0 \pm 0.3$ & $2.8 \pm 0.3$ \\
\hline & Treated & $0.8 \pm 0.2$ & $1.3 \pm 0.3$ & $1.3 \pm 0.4$ & $2.0 \pm 0.3$ & $2.8 \pm 0.2$ \\
\hline \multirow[t]{2}{*}{ Basal concentration (ng/ml) } & Control & $0.62 \pm 0.11$ & $0.63 \pm 0.07$ & $0.61 \pm 0.10$ & $1.12 \pm 0.12$ & $3.95 \pm 0.88$ \\
\hline & Treated & $0.48 \pm 0.08$ & $0.65 \pm 0.10$ & $0.83 \pm 0.27$ & $0.90 \pm 0.16$ & $3.58 \pm 0.75$ \\
\hline
\end{tabular}

Data are means \pm s.E.M. $\left(n=6\right.$ rams, unless indicated otherwise in parentheses). ${ }^{*}$ Indicates a subtle difference $(P<0.10)$ between groups $(\mathrm{LH}$ pulse amplitude).

aPhotoperiod was 4 months of long days ( $16 \mathrm{~h}$ light:8 $\mathrm{h}$ darkness, LD) followed by 1 month of short days ( $8 \mathrm{~h}$ light:16 h darkness, SD). ${ }^{\mathrm{b}} \mathrm{Hormonal}$ parameters are based on blood samples taken from the jugular vein every $20 \mathrm{~min}$ for $6 \mathrm{~h}$.

was also greater in the treated rams in these 3 months, although the enhancement of FSH peak amplitude and total $3 \mathrm{~h}$ response was not quite as apparent $(P<0.10)$ in the final month of long days (data not shown).

\section{Testosterone response to $\mathrm{LH}$ injection}

$\mathrm{LH}$ treatment (three $5 \mu \mathrm{g}$ doses given $20 \mathrm{~min}$ apart) consistently produced an LH peak with an amplitude of about $6 \mathrm{ng} / \mathrm{ml}$. Serum LH concentration peaked $60 \mathrm{~min}$ after LH injection began and then declined to basal values over the next $2 \mathrm{~h}$. The LH challenge elicited robust rises in serum testosterone concentration that peaked within $40 \mathrm{~min}$ after the $\mathrm{LH}$ peak (Fig. 4A). The testosterone response in the control rams did not change during long days. In contrast, testes of the bromocriptine-treated rams became less responsive to the $\mathrm{LH}$ challenge such that by the end of long days, testosterone peak height and total $3 \mathrm{~h}$ response (Fig. 4B) were reduced $(P<0.05)$ by more than $20 \%$. Similar differences were observed between groups in the last 2 months of long days. The testosterone response was greater $(P<0.01)$ and the same in all rams in short days.

\section{Testicular $\mathrm{LH}$ and $\mathrm{FSH}$ receptors}

$\mathrm{LH}$ receptor-binding activity in the testis did not differ between groups or months when expressed as per mg membrane protein (Fig. 5A). In contrast, LH receptorbinding per testis steadily increased $(P<0.01)$ by more than $80 \%$ for the control rams after the second month of
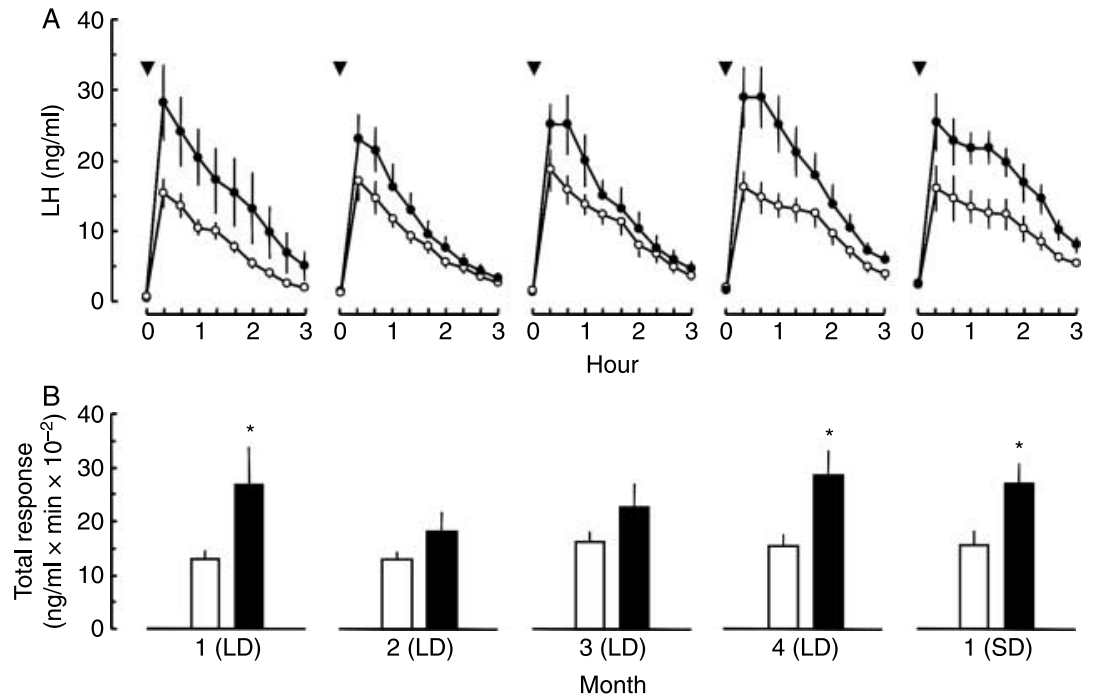

Figure 3 (A) Serum LH concentration at $20 \mathrm{~min}$ intervals and (B) total $\mathrm{LH}$ response (area under profile) for control rams $(\bigcirc, \square)$ and bromocriptine-treated (4 mg/day s.c.) rams $(\boldsymbol{\bullet}, \mathbf{\square})$ given single injections (i.v.) of $3 \mu \mathrm{g}$ natural sequence GNRH. Solid triangles in (A) mark the time of GNRH injection. Rams were kept under 4 months of long days ( $16 \mathrm{~h}$ light: $8 \mathrm{~h}$ darkness, LD) followed by 1 month of short days ( $8 \mathrm{~h}$ light: $16 \mathrm{~h}$ darkness, SD). Data are means \pm s.E.M. $(n=6$ rams $)$.

*Indicates a significant $(P<0.05)$ difference between groups. 

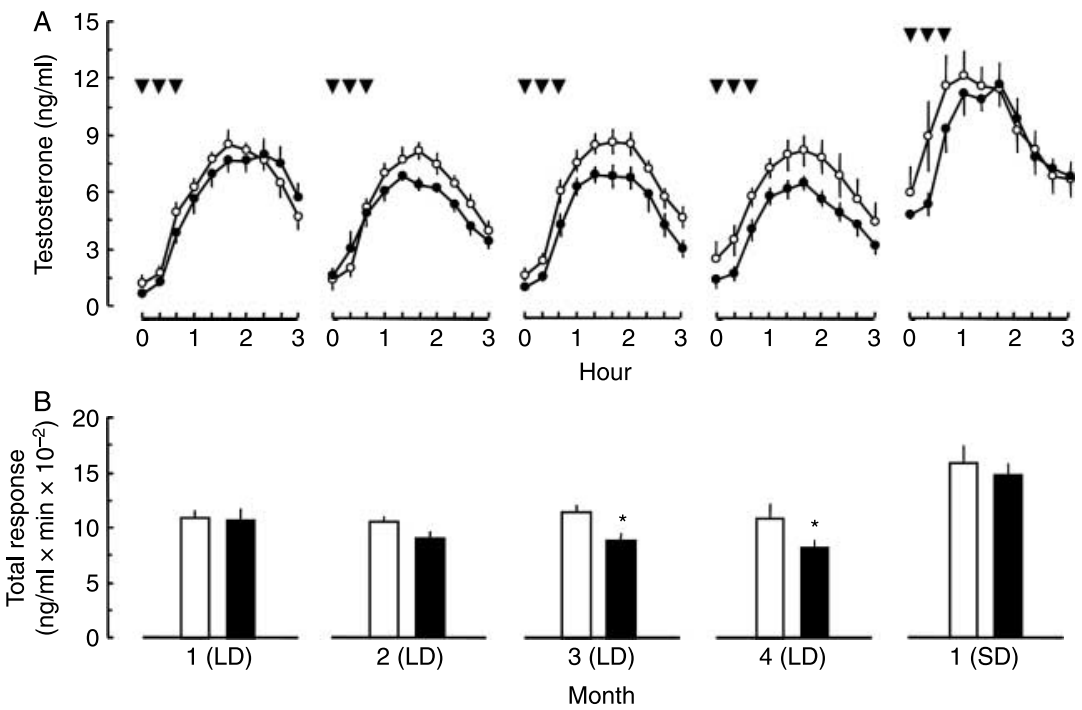

Figure 4 (A) Serum testosterone concentration at $20 \mathrm{~min}$ intervals and (B) total testosterone response (area under profile) for control rams $(\bigcirc, \square)$ and bromocriptine-treated (4 mg/day s.c.) rams $(\boldsymbol{\bullet}, \mathbf{\square}$ given series of three injections (i.v.) of $5 \mu \mathrm{g} \mathrm{NIH-}$ oLH-S24. Solid triangles in (A) mark the times of LH injection. Rams were kept under 4 months of long days ( $16 \mathrm{~h}$ light: $8 \mathrm{~h}$ darkness, LD) followed by 1 month of short days ( $8 \mathrm{~h}$ light: $16 \mathrm{~h}$ darkness, SD). Data are means \pm S.E.M. $(n=5$ or 6 rams).

*Indicates a significant $(P<0.05)$ difference between groups. long days (Fig. 5B). Total $\mathrm{LH}$ binding for the treated rams remained constant under long days, but increased $(P<0.01)$ by $80 \%$ during the month of short days. Treated rams had noticeably fewer $(30 \%, P<0.10) \mathrm{LH}$ receptors than the controls at the end of long days.

Temporal changes were seen in the concentration of $\mathrm{FSH}$ receptors in the testis. For rams generally, FSH binding per $\mathrm{mg}$ membrane protein declined $(P<0.05)$ by $30 \%$ between the third month of long days and the end of short days (Fig. 5C). FSH receptor binding per testis increased $(P<0.01)$ by $60 \%$ during this same period (Fig. 5D). At no time were either of the two measures of testicular FSH receptors unusually low for the bromocriptine-treated rams.

Affinity constants of the $\mathrm{LH}$ and FSH receptors at the end of short days did not differ between groups. The $K_{\mathrm{a}}$ value for the $\mathrm{LH}$ receptor was $1.89 \pm 0.34 \times 10^{9} \mathrm{M}^{-1}$ for the control rams and $1.89 \pm 0.32 \times 10^{9} \mathrm{M}^{-1}$ for the bromocriptine-treated rams. Corresponding $K_{\mathrm{a}}$ values for the FSH receptor were $8.18 \pm 0.62 \times 10^{9} \mathrm{M}^{-1}$ and $8.95 \pm 1.09 \times 10^{9} \mathrm{M}^{-1}$.

\section{Correlates of testicular function}

Blood testosterone concentration (indicative of Leydig cell function) was highly correlated with $\mathrm{LH}$ pulse frequency $(r=0.66-0.84, P<0.001)$ and basal $\mathrm{LH}$ concentration $(r=0.81-0.84, P<0.001)$ in both groups of rams (Table 2). Testosterone concentration was also correlated $(r=0.61, P<0.01)$ with the total number of $\mathrm{LH}$ receptors in the testis, but only in the control rams. Relationships between $\mathrm{LH}$ receptor number and parameters of the testosterone response to $\mathrm{LH}$ injection were consistently low and nonsignificant $(r=0.34-0.38$,
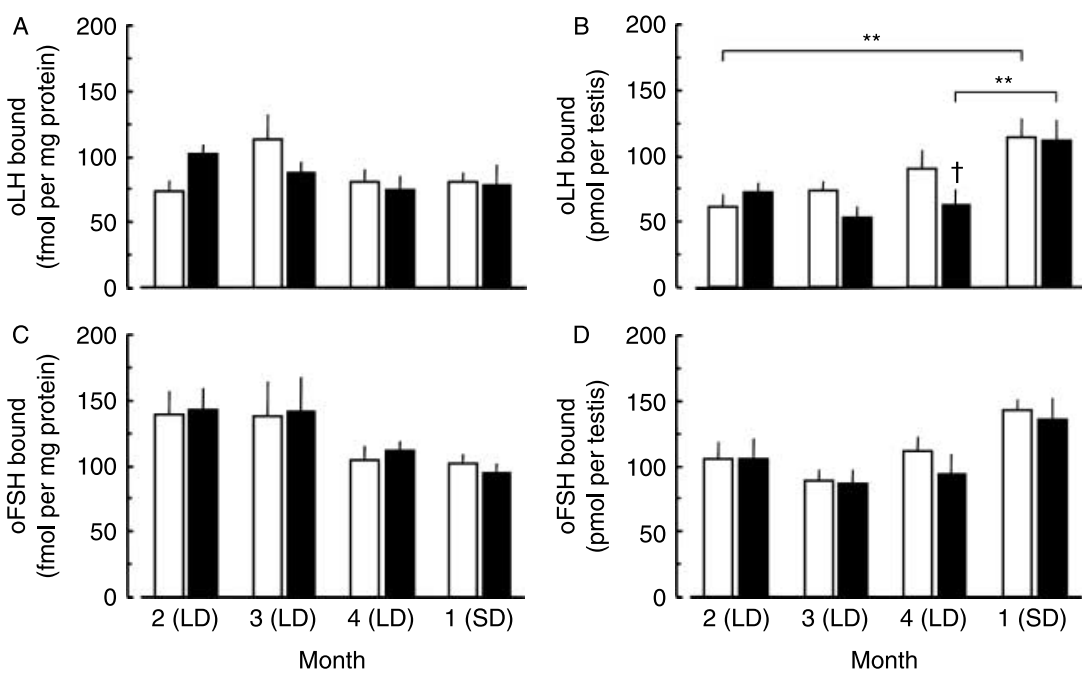

Figure 5 Testicular $\mathrm{LH}$ receptor binding of oLH expressed as (A) fmol per mg membrane protein and (B) pmol per testis, and FSH receptor binding of oFSH expressed as (C) fmol per mg membrane protein and (D) pmol per testis for control rams ( $\square$ ) and bromocriptine-treated (4 mg/day s.c.) rams ( $\boldsymbol{\square})$. Rams were kept under 4 months of long days ( $16 \mathrm{~h}$ light: $8 \mathrm{~h}$ darkness, LD) followed by 1 month of short days ( $8 \mathrm{~h}$ light: $16 \mathrm{~h}$ darkness, SD). Data are means \pm S.E.M. $(n=5$ or 6 rams $)$.

**Indicate a significant $(P<0.01)$ change in time within group, and ${ }^{+}$indicates a subtle difference $(P<0.10)$ between groups. 
Table 2 Correlation between indices of Leydig cell function (blood testosterone) and Sertoli cell function (testes mass) and select hormonal parameters for control and bromocriptine-treated rams across the regressed and early redevelopment stages of the 'seasonal' testicular cycle.

\begin{tabular}{|c|c|c|c|c|c|}
\hline \multirow[b]{2}{*}{ Functional index } & \multirow[b]{2}{*}{ Correlate $^{a}$} & \multicolumn{2}{|c|}{ Control rams } & \multicolumn{2}{|c|}{ Treated rams } \\
\hline & & Error $d_{f}$ & $r$ & Error $d_{f}$ & $r$ \\
\hline \multirow[t]{4}{*}{ Blood testosterone $^{\mathrm{b}}$} & LH basal concentration & 22 & $0.84^{\ddagger}$ & 22 & $0.81^{\ddagger}$ \\
\hline & LH pulse frequency & 22 & $0.84^{\ddagger}$ & 22 & $0.66^{\ddagger}$ \\
\hline & LH pulse amplitude & 19 & $0.49 *$ & 19 & 0.32 \\
\hline & LH receptors per testis & 20 & $0.61^{+}$ & 21 & 0.31 \\
\hline \multirow[t]{2}{*}{ Testes mass ${ }^{\mathrm{c}}$} & FSH concentration & 22 & $0.61^{\dagger}$ & 22 & $0.62^{+}$ \\
\hline & FSH receptors per testis & 22 & $0.86^{\ddagger}$ & 22 & $0.90^{\ddagger}$ \\
\hline
\end{tabular}

$r$-Values are Pearson's or Spearman's rank (LH pulse frequency) correlation coefficients ${ }^{*} P<0.05,{ }^{\dagger} P<0.01$ and ${ }^{\ddagger} P<0.001$.

${ }^{a}$ Hormonal correlates are based on serial blood collections (sample taken every 20 min for $6 \mathrm{~h}$ ). FSH mean serum concentrations were converted to logarithms. ${ }^{\mathrm{b}}$ Blood testosterone is the mean serum concentration during the $6 \mathrm{~h}$ collection period. ${ }^{\mathrm{c}}$ Testes mass was estimated from scrotal circumference at the time of testicular biopsy.

$P>0.05$ ). In both groups of rams, testes mass (indicative of Sertoli cell function) was more strongly correlated with the total number of FSH receptors in the testis $(r=0.86-0.90, P<0.001)$ than with blood FSH concentration $(r=0.61-0.62, P<0.01)$.

\section{Discussion}

Our study centered on ways that PRL could regulate testosterone secretion in the adult ram. Novel findings on DLS rams suggest that 1) PRL helps preserve the functional integrity of Leydig cells in the regressed testes, and that this action involves more than $\mathrm{LH}$ receptors, and 2) PRL directly impairs the secretory capability of pituitary gonadotrophs when the testes are developing or regressing, which can result in slightly smaller episodic LH releases. However, neither action of PRL alters testosterone concentration (i.e. values reflecting natural episodic secretions) in peripheral blood.

All rams displayed typically low testosterone concentrations in the regressed stage of the 'seasonal' testicular cycle (Sanford et al. 1993, 2002). Diminished testosterone production by the testes in this stage is mainly due to atrophy of Leydig cells (Hochereau-de Reviers et al. 1985, 1992) and decreases in the activity of three regulatory proteins that are highly dependent upon $\mathrm{LH}$, namely STAR protein and the cytochrome P450 cholesterol side-chain cleavage (CYP11A1, P450scc) and 17 $\alpha$-hydroxylase C17-C20 lyase (CYP17A1, P450c17) enzymes (Price et al. 2000). While LH is the primary hormone regulating the structural and functional integrity of Leydig cells (Mendis-Handagama 1997, Lejeune et al. 1998), present results indicate that, as in male rodents (Bole-Feysot et al. 1998, Lejeune et al. 1998), PRL assists in maintaining the competency of Leydig cells in the ram. However, this beneficial effect of PRL seems to be restricted to when the testes are regressed and is apparent only when Leydig cells are challenged with $\mathrm{LH}$, which in the control rams elevated blood testosterone concentration $35 \%$ higher than did natural $\mathrm{LH}$ pulses.
It is evident that testosterone secretion by the regressed testes was both intrinsically low and submaximally stimulated by a relatively weak $\mathrm{LH}$ pulse signal. Our belief was that under these conditions PRL would keep Leydig cells in a high 'state of readiness' to $\mathrm{LH}$ stimulation by maintaining the number of $\mathrm{LH}$ receptors on the cell surface. Indeed, rams given bromocriptine did have fewer LH receptors in the testis than did the controls, but it is uncertain whether this would have affected testosterone secretion. The loss of $\mathrm{LH}$ receptors (25-30\%) only approached that required $(>30 \%$ ) to reduce the sensitivity of Leydig cells to $\mathrm{LH}$ (Purvis et al. 1978) and was significant $(P<0.10)$ on only one of the two occasions in which the testosterone response to $\mathrm{LH}$ injection was diminished $(20 \%$ in both instances). It is clear that $\mathrm{LH}$ receptor numbers were less dependent upon PRL in our rams than in the adult rat (Pakarinen et al. 1994), mouse (Takase et al. 1990), and hamster (Klemcke et al. 1984) where bromocriptine treatment results in a $40-70 \%$ loss of $\mathrm{LH}$ binding in the testis. Preliminary results (Regisford \& Katz 1994) indicate that PRL might play a more prominent role in maintaining $\mathrm{LH}$ receptors and testosterone production in the ram when the testes are fully developed.

PRL's support of testosterone secretion in rams likely involves more than regulating LH receptors. Suppression of PRL secretion can result in hyperplasia of Leydig cells, but the cells tend to be small and unable to sustain intratesticular testosterone concentration (Barenton \& Pelletier 1980, Barenton et al. 1982). These events occur without changes in $\mathrm{LH}$ release or the number of $\mathrm{LH}$ receptors per Leydig cell. Furthermore, hypothalamopituitary disconnected (HPD) rams continue to secrete PRL, but virtually no LH and FSH (Lincoln et al. 1996). Leydig cells in HPD rams retain PRL receptors (Jabbour \& Lincoln 1999) and a low level of steroidogenic activity (i.e. cells express P450c17 enzyme and are able to secrete a small amount of testosterone). These and present results indicate that PRL could influence testosterone biosynthesis in the ram by acting beyond the $\mathrm{LH}$ receptor or independently of the $\mathrm{LH}$ signaling 
pathway. In this regard, low levels of PRL seem to augment hCG-induced steroidogenesis in MA-10 mouse Leydig tumor cells by increasing LH/hCG receptor number and (or) facilitating intracellular signal transduction (Weiss-Messer et al. 1996, Manna et al. 2001). PRL also induces/maintains the activity of several steroidogenic enzymes (e.g. P450scc and P450c17) in the rodent testis (Chandrashekar \& Bartke 1988, Dombrowicz et al. 1992).

The second aim of our study was to determine if PRL regulates testosterone secretion in rams indirectly by attenuating the $\mathrm{LH}$ response of the pituitary to GNRH pulses, thus tempering the size of episodic LH releases. LH pulse amplitude is known to be an important determinant of testosterone pulse amplitude when testosterone secretion is low (Wilson \& Lapwood 1978, Rhim et al. 1993). Suppression of PRL secretion in the DLS rams resulted in a significantly greater release of $\mathrm{LH}$ than normal when the pituitary was challenged with $3 \mu \mathrm{g}$ of GNRH in the two transition and the late regression stages of the testicular cycle. However, natural LH pulses only tended to be larger (transition stages) and, as would be expected, did not increase the amplitude of testosterone pulses. The level of stimulation provided by GNRH pulses would have been several fold less than that of the GNRH challenge and thus probably too weak to fully reveal PRL's dampening effect on the dynamics of LH release. A $250 \mathrm{ng}$ dose of GNRH is all that is required to produce a physiological 'GNRH pulse' in hypophyseal portal blood in adult sheep (Karsch et al. 1987, Rhim et al. 1993).

Based on the serum LH profiles of the bromocriptinetreated rams, it appears that the GNRH challenge was, in specific stages of the testicular cycle, able to provoke an unusually large release of $\mathrm{LH}$ from the 'readily releasable' pool of LH in the pituitary gland (Bremner et al. 1980, Evans et al. 1995). Larger LH releases in the treated rams were always accompanied by larger releases in $\mathrm{FSH}$, thereby maintaining a normal ratio between the magnitudes of the $\mathrm{LH}$ and FSH responses. Perhaps the most plausible explanation for why the GNRH challenge was able to elicit a greater pituitary response is that a local paracrine action of PRL was abolished. It is known that, for the ewe, about $50 \%$ of the gonadotrophs that express LHB and FSHB subunits also express PRL receptors (Tortonese et al. 1998) and that $\mathrm{PRL}$, in the presence of dopamine, blocks the $\mathrm{LH}$ response of primary pituitary cell cultures to GNRH (Gregory et al. 2004). The present in vivo results suggest that PRL and dopamine may interact to exert a synergistic inhibitory effect on gonadotropin secretion in rams as well as ewes, and that this mechanism may operate in a season-dependent manner in both sexes. Decreases in the action of the gonadal-feedback hormones estrogen and inhibin would not explain the increase in pituitary responsiveness to GNRH since PRL has little effect on the blood levels of these hormones (Lincoln et al. 2001, Sanford \& Dickson 2008).

Also of interest in this study is that DLS rams with suppressed PRL secretion had a slight (2 week) delay in the onset of testicular recrudescence in long days. Adult rams of the moderately seasonal Romanov breed show a similar delay in testes growth when administered bromocriptine in late spring and early summer (Barenton \& Pelletier 1980). The later onset of testis growth in our rams happened when their blood FSH concentrations were increasing more slowly than usual, suggesting the delay was caused by inadequate FSH stimulation. However, while 'seasonal' increases in FSH secretion and numbers of $\mathrm{FSH}$ receptors play pivotal roles in regulating testicular redevelopment in DLS rams (Sanford et al. 2002), this regulation does not appear to include the early part of the rise in FSH secretion (Sanford \& Dickson 2008). Serum FSH continued to increase in short days to normal peak values in all rams. Surprisingly, testes in the bromocriptine-treated rams grew much faster than usual, such that testes mass was more in line with that of the controls by the end of short days. Thus, it appears that the final increases in FSH and testosterone, the main hormones regulating germ cell proliferation (Courot \& Ortavant 1981, Kilgour et al. 1994), were able to compensate for the chronic reduction in PRL.

Evidence suggests that testes began enlarging slightly later in the treated rams because PRL was missing. Receptors for PRL have been located in several types of germ cells (pachytene spermatocytes, round and elongating spermatids) in the ram testis, implying that PRL acts on cell division and (or) differentiation and alters the efficiency of spermatogenesis (Jabbour \& Lincoln 1999). This hypothesis is supported by other studies showing that PRL induces testicular growth in Soay HPD rams with a response delay of 4-8 weeks (Lincoln et al. 1996), and that selective inhibition of PRL secretion in Suffolk rams reduces (50\%) both testicular growth and sperm production during mid-redevelopment (Sanford \& Dickson 2008). Therefore, we propose that as the testes of DLS rams emerge from the regressed state, PRL targets germ cells as well as Leydig cells and stimulates early testicular growth. Of note in our studies on two domestic breeds is that PRL played a less significant role in regulating the annual testicular cycle in the moderately seasonal DLS ram than in the highly seasonal Suffolk ram (ewes receptive $\sim 215$ vs 115 days, respectively).

We conclude that PRL is part of the intricate regulation of the pituitary-gonadal system in moderately seasonal DLS rams. PRL, in a stage-dependent fashion, seems to 1) impair the release of 'readily releasable' $\mathrm{LH}$ from gonadotrophs, which may be 'hinted at' by lower amplitude episodic $\mathrm{LH}$ releases, 2) help maintain the functional integrity of Leydig cells (i.e. their secretory capability and perhaps surface $\mathrm{LH}$ receptors), and 
3) promote testicular growth, presumably by increasing germ cell mass. However, PRL has minimal impact on testicular recrudescence per se as testes growth is only slightly (and transiently) advanced and testosterone levels in peripheral blood are not any higher than when PRL is absent.

\section{Materials and Methods}

\section{Animals and management}

Twelve adult DLS rams were provided from the Agriculture and Agri-Food Canada research flock in La Pocatière, Québec for this investigation. The DLS is a newly registered Canadian breed of sheep developed from Dorset, Leicester and Suffolk stock. Rams were kept in two adjacent, light-controlled rooms measuring $3 \mathrm{~m} \times 3 \mathrm{~m}$. Light intensity in the centre of the rooms at eye level of the rams was 90 lux. Ambient temperature in the rooms was not strictly controlled and varied with the ambient temperature out-of-doors (Fig. 1A). Rams were fed a diet of timothy hay and grain, and had free access to a mineralvitamin mixture and drinking water. Care and treatment of the experimental animals were in accordance with guidelines prescribed by the Canadian Council on Animal Care.

\section{Experimental protocol}

Rams were taken from natural photoperiod (latitude $45^{\circ} \mathrm{N}$ ) and placed in the light-controlled rooms in early June. They were exposed to 4 months of short days ( $8 \mathrm{~h}$ light: $16 \mathrm{~h}$ darkness) followed by 4 months of long days ( $16 \mathrm{~h}$ light: $8 \mathrm{~h}$ darkness) and another 5 weeks of short days. The testes of rams were expected to finish developing and start regressing during short days, and then finish regressing and start redeveloping during long days (Sanford et al. 1993, 2002). The experimental period began when the switch was made from short to long days (October 1) and ended after the second short-day period (March 6).

Throughout the experimental period, six of the rams were treated with the dopamine D2 receptor agonist bromocriptine (2-bromo- $\alpha$-ergocryptine, Sandoz Canada, Dorval, Québec, Canada) to suppress PRL secretion. Each ram received a daily s.c. injection of $4 \mathrm{mg}$ dissolved in $1.0 \mathrm{ml}$ of ethanol: $0.9 \%$ saline $(60: 40 \mathrm{v} / \mathrm{v})$. This daily dose of the drug has been used extensively with adult rams of the heavier breeds (Barenton \& Pelletier 1980, Regisford \& Katz 1993, Sanford \& Dickson 2008) and would not act directly (i.e. independently of PRL) on hormone secretion at the level of the hypothalamus, pituitary or testis (Lincoln et al. 2001). The remaining six rams received daily injections of vehicle only. Sites of injection were the areas free of wool in the vicinity of the fore and hind limbs. Rams were routinely injected at $0930 \mathrm{~h}$, but injection was delayed until $1430 \mathrm{~h}$ on days when serial blood samples were collected. Rams were 20 months of age and weighed $59 \pm$ $2 \mathrm{~kg}$ (mean \pm s.E.M.) when the experimental period began. Body weight increased $(P<0.01)$ by $10 \%$ during the 5 months of bromocriptine injection.

Evaluations were done to determine the location and extent of PRL involvement in regulating the pituitary-gonadal system. Testis size, blood concentrations of PRL and FSH, and parameters of episodic $\mathrm{LH}$ and testosterone secretion were assessed in the late regression, regressed and early redevelopment stages of the 'seasonal' testicular cycle. Pituitary responses ( $\mathrm{LH}$ and $\mathrm{FSH}$ ) to $\mathrm{GNRH}$ injection and the testes response (testosterone) to $\mathrm{LH}$ injection were also examined during these stages. The two challenges were designed to provide stronger stimulation than natural pulse secretions of GNRH and LH. A biopsy of the testis was performed a few days after each $\mathrm{LH}$ provocation test to determine $\mathrm{LH}$ and $\mathrm{FSH}$ receptor-binding activity.

\section{Testicular size measurements}

Scrotal circumference was measured about every 2 weeks from the time that rams entered the light-controlled rooms until the study was completed. Paired-testes mass was estimated from scrotal circumference at specific time points with a regression equation reported by Knight (1977) for Romney rams. Estimates of testes mass were used in defining the stages of the testicular cycle and in determining testicular growth rates and the total number of $\mathrm{LH}$ and $\mathrm{FSH}$ receptors in the testis.

\section{Blood sampling and hormone treatments}

Three serial blood collections were done each month, usually during the second or third week. In each collection, blood $(7 \mathrm{ml})$ was withdrawn from the jugular vein by venipuncture every 20 min for $6 \mathrm{~h}$, beginning at $0830 \mathrm{~h}$. The first collection (day 1 ) was taken unaccompanied by hormone treatment. In the second collection (day 3), $3 \mu \mathrm{g}$ of natural sequence GNRH in $1.0 \mathrm{ml}$ of saline were injected into the jugular vein immediately after the sixth blood sample was taken. This dose of GNRH was chosen to moderately stimulate the pituitary (Sanford \& Robaire 1990). In the third collection (day 5), $5 \mu \mathrm{g}$ of $\mathrm{NIH}$-oLH-S24 in $1.0 \mathrm{ml}$ of saline were injected into the jugular vein immediately after the sixth, seventh, and eighth blood samples were taken. The intent was to produce a prolonged rise in the blood $\mathrm{LH}$ with an amplitude similar to that of the episodic LH releases that occur during testicular recrudescence (Sanford \& Baker 1990, Sanford et al. 1993). The LH challenge probably caused maximal or near maximal stimulation of the testes.

\section{Hormone assays and secretion parameters}

Double-antibody RIAs were used to determine serum concentrations of PRL (Sanford et al. 1978), FSH (Cheng et al. 1981), LH (Niswender et al. 1969, Sanford 1987), and testosterone (Sanford 1985). RPs in the pituitary hormone assays were NIHoPRL-S12, NIH-oFSH-S12 and NIH-oLH-S14. Minimum detectable concentrations of $\mathrm{PRL}, \mathrm{FSH}, \mathrm{LH}$ and testosterone were $4.0,2.5,0.25$, and $0.20 \mathrm{ng} / \mathrm{ml}$ respectively. The intra- and inter-assay coefficients of variation in the four assay procedures were $<12 \%$.

Mean PRL and FSH concentrations were determined by assaying serum pools (equal aliquots of 18 sera) prepared from the first of the three monthly blood collections. Individual sera were assayed for $\mathrm{LH}$ and testosterone to determine parameters of episodic secretion. Increases in serum concentration were 
identified as pulses when peak values occurred within 40 min (LH) or 60 min (testosterone) of the preceding basal value. A peak value also had to exceed the basal value by twice the detection limit of the assay and by twice the intra-assay variance. Pulse frequency was defined as the total number of pulses occurring over the $6 \mathrm{~h}$ period, and pulse amplitude as the average difference between the peak and the preceding basal serum concentrations. Basal (interpulse) concentration was defined as the mean of all low values not associated with a pulse(s). Hormone values for the 18 sera were averaged to determine mean concentration.

In the first provocation test (GNRH challenge), the amplitude of the $\mathrm{LH}$ and $\mathrm{FSH}$ responses was defined as the difference between the mean of the six pre-injection concentrations and the single highest value on the response curve. Total area under the $3 \mathrm{~h}$ response profile above the pre-injection value was determined from a series of time and concentration coordinates with GraphPad Prism version 3.02 (Motulsky 1999). In the second provocation test ( $\mathrm{LH}$ challenge), the height of the testosterone response was defined as the largest mean value obtained from two consecutive concentrations on the response curve. Total area under the $3 \mathrm{~h}$ response profile was determined with GraphPad Prism. The area occupied by a theoretical decline in testosterone from time 0 concentration, assuming a half-life of 10 min (Darbeïda \& Brudieux 1980, Schanbacher et al. 1987), was subtracted from the total area. The corrected total area is an accurate reflection of the amount of testosterone secreted in response to the $\mathrm{LH}$ challenge since endogenous $\mathrm{LH}$ release would have been inhibited as soon as $\mathrm{LH}$ injection began (Sanford \& Ponzilius 1989).

\section{Collection of testicular tissue}

Four or five days after the monthly LH challenge was given, testicular tissue was collected to determine $\mathrm{LH}$ and $\mathrm{FSH}$ receptor-binding activity. Details of the biopsy procedure have previously been given (Sanford 1989). In essence, 1-2 g tissue were removed from the testis after a $2-3 \mathrm{~cm}$ incision had been made in the mid-region of the scrotal sac and in the underlying layers of the testicular capsule. Soon after the final tissue samples were taken, rams were castrated to obtain sufficient tissue to determine binding affinities of the $\mathrm{LH}$ and $\mathrm{FSH}$ receptors. All samples of testis tissue were immediately frozen in liquid nitrogen and stored at $-70{ }^{\circ} \mathrm{C}$ until analyzed for receptor binding. Castration of rams was done as reported earlier (Price et al. 2000).

\section{$\mathbf{L H}$ and $\mathrm{FSH}$ receptor binding assays}

Unoccupied LH and FSH receptors were measured by specific binding of ${ }^{125} \mathrm{I}$-labeled ovine $\mathrm{LH}$ and $\mathrm{FSH}$ to plasma-membrane fractions prepared from testicular tissue (Yarney et al. 1988, Sanford \& Baker 1990). The specific activities of the labeled hormone preparations were $50 \mu \mathrm{Ci} / \mu \mathrm{g}$ for ${ }^{125} \mathrm{I}$-oLH and $75 \mu \mathrm{Ci} / \mu \mathrm{g}$ for ${ }^{125} \mathrm{I}$-oFSH. Membrane preparations (equivalent to $25 \mathrm{mg}$ wet tissue) were incubated with radiolabeled hormone ( $\sim 60000$ c.p.m. or $400-500 \mathrm{pg})$ in single point assays for either $18 \mathrm{~h}$ at $4{ }^{\circ} \mathrm{C}$ ( $\mathrm{LH}$ binding assay) or $16 \mathrm{~h}$ at $25^{\circ} \mathrm{C}$ (FSH binding assay). Intra- and inter-assay variances were
$<12 \%$. The amount of membrane-bound $\mathrm{LH}$ and $\mathrm{FSH}$ was assessed on a per mg membrane protein and per testis basis.

Scatchard analysis of the $\mathrm{LH}$ and $\mathrm{FSH}$ binding data for the final testis tissue samples (incubated with 0-500 ng unlabeled hormone) was done to determine the apparent association constants $\left(K_{\mathrm{a}}\right)$ of the receptors. Estimates of $K_{\mathrm{a}}$ were first made with the computer program of McPherson (1983). These initial estimates were used in the nonlinear curve-fitting program of Munson \& Rodbard (1980) to obtain the final parameter values.

\section{Statistical analyses}

Data were transformed to logarithms for statistical analysis when variances of group means were found to be unequal with the Bartlett's test. Most of the data were analyzed by two-way ANOVA for repeated measures with the PROC MIXED procedure of SAS (1989). Group, time, and the group-by-time interaction were included in the model. A one-way ANOVA for repeated measures was used to determine the significance of monthly differences in serum PRL concentration in the control rams. Least squares means were compared with the PDIFF (probability difference) test. Group differences in testicular growth rate and in $K_{\mathrm{a}}$ values for the $\mathrm{LH}$ and $\mathrm{FSH}$ receptors were tested for significance with the Student's $t$-test. Pearson or Spearman's rank (when LH pulse frequency was a variable) correlation coefficients were determined between select blood hormone and testis parameters.

Estimates of $\mathrm{LH}$ and $\mathrm{FSH}$ receptor binding were not obtained on testicular biopsies taken in the first month of the experimental period as these samples were accidentally thawed and had to be discarded. The testosterone response to the last LH challenge was suspect for one control and one treated ram. Their parameter values were abnormally high and identified $(P<0.05)$ as outliers by the Grubb's test (Motulsky 1999). These data were excluded from the analyses.

\section{Declaration of interest}

The authors declare that there is no conflict of interest that would prejudice the impartiality of this scientific work.

\section{Funding}

This work was supported by the Medical Research Council of Canada (grant MA-9249).

\section{Acknowledgements}

We thank Ms Donna Leggee and Mr Anthony Peirce for excellent technical assistance; Mr Grant Rogers for care of the research animals; and Dr Gerard Cooke, Health Canada, Ottawa, for constructive comments on the manuscript. Pituitary hormone preparations were generously donated by Dr M Ram Sairam, Clinical Research Institute of Montreal (testicular LH and FSH receptor assays) and the NIDDK (serum hormone assays). 


\section{References}

Barenton B \& Pelletier J 1980 Prolactin, testicular growth and LH receptors in the ram following light and 2-Br- $\alpha$-ergocryptine (CB-154) treatments. Biology of Reproduction 22 781-790.

Barenton B, Hochereau-de Reviers MT, Perreau C \& Poirier J-C 1982 Effects of induced hypoprolactinemia in the ram: plasma gonadotrophin levels, $\mathrm{LH}$ and FSH receptors and histology of the testis. Reproduction, Nutrition, Development 22 621-630.

Bartke A 2004 Prolactin in the male: 25 years later. Journal of Andrology 25 661-666.

Bole-Feysot C, Goffin V, Edery M, Binart N \& Kelly PA 1998 Prolactin (PRL), and its receptor: actions, signal transduction pathways and phenotypes observed in PRL receptor knockout mice. Endocrine Reviews 19 225-268.

Bremner WJ, Findlay JK, Lee VWK, de Kretser DM \& Cumming IA 1980 Feedback effects of the testis on pituitary responsiveness to luteinizing hormone-releasing hormone infusions in the ram. Endocrinology 106 329-336.

Chandrashekar V \& Bartke A 1988 Influence of endogenous prolactin on the luteinizing hormone stimulation of testicular steroidogenesis and the role of prolactin in adult male rats. Steroids 51 559-576.

Cheng KW, Simaraks S \& Palmer WM 1981 Characterization of a radioimmunoassay for ovine-FSH utilizing an antibovine $\mathrm{FSH}$ serum. Journal of Reproduction and Fertility 61 115-121.

Cheung CY 1983 Prolactin suppresses luteinizing hormone secretion and pituitary responsiveness to luteinizing hormone-releasing hormone by a direct action at the anterior pituitary. Endocrinology 113 632-638.

Courot M \& Ortavant R 1981 Endocrine control of spermatogenesis in the ram. Journal of Reproduction and Fertility Supplement 30 47-60.

Curlewis JD 1992 Seasonal prolactin secretion and its role in seasonal reproduction: a review. Reproduction, Fertility, and Development 4 $1-23$.

Curlewis JD \& McNeilly AS 1991 Prolactin short-loop feedback and prolactin inhibition of luteinizing hormone secretion during the breeding season and seasonal anoestrus in the ewe. Neuroendocrinology 54 279-285.

Darbeïda H \& Brudieux R 1980 Seasonal variations in plasma testosterone and dihydrotestosterone levels and in metabolic clearance rate of testosterone in rams in Algeria. Journal of Reproduction and Fertility $\mathbf{5 9}$ 229-235.

Dombrowicz D, Sente B, Closset J \& Hennen G 1992 Dose-dependent effects of human prolactin on the immature hypophysectomized rat testis. Endocrinology 130 695-700.

Evans NP, McNeilly JR \& Webb R 1995 Effects of indirect selection for pituitary responsiveness to gonadotropin-releasing hormone on the storage and release of luteinizing hormone and follicle-stimulating hormone in prepubertal male lambs. Biology of Reproduction $\mathbf{5 3}$ 237-243.

Freeman ME, Kanyicska B, Lerant A \& Nagy G 2000 Prolactin: structure, function, and regulation of secretion. Physiological Reviews $\mathbf{8 0}$ 1523-1631.

Gregory SJ, Townsend J, McNeilly AS \& Tortonese DJ 2004 Effects of prolactin on the luteinizing hormone response to gonadotropin-releasing hormone in primary pituitary cell cultures during the ovine annual reproductive cycle. Biology of Reproduction 70 1299-1305.

Hochereau-de Reviers MT, Perreau C \& Lincoln GA 1985 Photoperiodic variations of somatic and germ cell populations in the Soay ram testis. Journal of Reproduction and Fertility 74 329-334.

Hochereau-de Reviers MT, Perreau C, Pisselet C \& Pelletier J 1992 Effect of a 2-month light cycle regimen on testicular parameters of adult Ile-de-France rams. Microscopy Research and Technique 20 268-273.

Jabbour HN \& Lincoln GA 1999 Prolactin receptor expression in the testis of the ram: localization, functional activation and the influence of gonadotrophins. Molecular and Cellular Endocrinology 148 151-161.

Karsch FJ, Cummins JT, Thomas GB \& Clarke IJ 1987 Steroid feedback inhibition of pulsatile secretion of gonadotropin-releasing hormone in the ewe. Biology of Reproduction 36 1207-1218.

Kilgour RJ, Courot M, Pisselet C, Dubois MP \& Sairam MR 1994 Inhibition of FSH but not $\mathrm{LH}$ affects spermatogenesis in the mature ram. Animal Reproduction Science 34 253-264.
Klemcke HG, Bartke A \& Borer KT 1984 Regulation of testicular prolactin and luteinizing hormone receptors in golden hamsters. Endocrinology 114 594-603.

Knight TW 1977 Methods for the indirect estimation of testes weight and sperm numbers in Merino and Romney rams. New Zealand Journal of Agricultural Research 20 291-296.

Koike K, Miyake A, Aono T, Sakumoto T, Ohmichi M, Yamaguchi M \& Tanizawa O 1991 Effect of prolactin on the secretion of hypothalamic GnRH and pituitary gonadotropins. Hormone Research 35 (Supplement 1) 5-12.

Lejeune H, Habert R \& Saez JM 1998 Origin, proliferation and differentiation of Leydig cells. Journal of Molecular Endocrinology 20 $1-25$.

Lincoln GA 1990 Correlation with changes in horns and pelage, but not reproduction, of seasonal cycles in the secretion of prolactin in rams of wild, feral and domesticated breeds of sheep. Journal of Reproduction and Fertility Abstract Series 90 285-296.

Lincoln GA \& Tortonese DJ 1997 Prolactin: an impotent inhibitor of gonadotrophin secretion in sheep? Journal of Reproduction and Fertility 1915.

Lincoln GA \& Tortonese DJ 1999 Prolactin replacement fails to inhibit reactivation of gonadotropin secretion in rams treated with melatonin under long days. Biology of Reproduction 60 602-610.

Lincoln GA, Lincoln CE \& McNeilly AS 1990 Seasonal cycles in the blood plasma concentration of $\mathrm{FSH}$, inhibin and testosterone, and testicular size in rams of wild, feral and domesticated breeds of sheep. Journal of Reproduction and Fertility 88 623-633.

Lincoln GA, Clarke IJ \& Sweeney T 1996 'Hamster-like' cycles in testicular size in the absence of gonadotrophin secretion in HPD rams exposed to long-term changes in photoperiod and treatment with melatonin. Journal of Neuroendocrinology 8 855-866.

Lincoln GA, Townsend J \& Jabbour HN 2001 Prolactin actions in the sheep testis: a test of the priming hypothesis. Biology of Reproduction $\mathbf{6 5}$ 936-943.

Manna PR, El-Hefnawy T, Kero J \& Huhtaniemi IT 2001 Biphasic action of prolactin in the regulation of murine Leydig cell tumor cell functions. Endocrinology 142 308-318.

McPherson GA 1983 A practical computer-based approach to the analysis of radioligand binding experiments. Computer Programs in Biomedicine 17 107-114.

Mendis-Handagama SMLC 1997 Luteinizing hormone on Leydig cell structure and function. Histology and Histopathology 12 869-882.

Misztal T, Romanowicz K, Wankowska M, Wojcik-Gladysz A \& Polkowska J 2005 Does prolactin influence the hypothalamo-pituitary GnRH-LH system in preovulatory-phase ewes? Reproductive Biology 5 31-49.

Motulsky HJ 1999 Analyzing Data with GraphPad Prism, San Diego CA: GraphPad Software Inc.

Munson PJ \& Rodbard D 1980 LIGAND: a versatile computerized approach for characterization of ligand-binding systems. Analytical Biochemistry 107 220-239.

Niswender GD, Reichert LE Jr, Midgely AR Jr \& Nalbandov AV 1969 Radioimmunoassay for bovine and ovine LH. Endocrinology $\mathbf{8 4}$ 1166-1173.

Pakarinen P, Niemimaa T, Huhtaniemi IT \& Warren DW 1994 Transcriptional and translational regulation of $\mathrm{LH}$, prolactin and their testicular receptors by hCG and bromocriptine treatments in adult and neonatal rats. Molecular and Cellular Endocrinology 101 $37-47$.

Price CA, Cooke GM \& Sanford LM 2000 Influence of season and low-level oestradiol immunoneutralization on episodic $\mathrm{LH}$ and testosterone secretion and testicular steroidogenic enzymes and steroidogenic acute regulatory protein in the adult ram. Journal of Reproduction and Fertility 118 251-262.

Purvis K, Clausen OPF, Brandtzaeg P \& Hansson V 1978 LH receptors and Leydig cell responsiveness to hCG in vitro. Archives of Andrology $\mathbf{1}$ 299-310.

Regisford EGC \& Katz LS 1993 Effects of bromocriptine-induced hypoprolactinaemia on gonadotrophin secretion and testicular function of rams (Ovis aries) during two seasons. Journal of Reproduction and Fertility 99 529-537. 
Regisford EGC \& Katz LS 1994 Testicular LH receptor numbers are dependent on serum prolactin (PRL) concentrations in the ram (Ovis aries). Biology of Reproduction $\mathbf{5 0}$ (Supplement 1) 112.

Rhim T-J, Kuehl D \& Jackson GL 1993 Seasonal changes in the relationships between secretion of gonadotropin-releasing hormone, luteinizing hormone, and testosterone in the ram. Biology of Reproduction 48 197-204.

Romanowicz K, Misztal T \& Barcikowski B 2004 The effects of intracerebroventricular infusion of prolactin on luteinizing hormone, testosterone and growth hormone secretion in male sheep. Animal Reproduction Science 81 261-271.

Sanford LM 1985 Evidence that estrogen regulation of testosterone secretion in adult rams is mediated by both indirect (gonadotropin dependent) and direct (gonadotropin independent) means. Journal of Andrology 6 306-314.

Sanford LM 1987 Luteinizing hormone release in intact and castrate rams is altered with immunoneutralization of endogenous estradiol. Canadian Journal of Physiology and Pharmacology 65 1442-1447.

Sanford LM 1989 Increases in testosterone secretion in adult rams with immunoneutralization of endogenous estradiol occur in the absence of increases in pulsatile $\mathrm{LH}$ release or testicular $\mathrm{LH}$ receptors. Acta Endocrinologica (Copenhagen) 120 180-186.

Sanford LM \& Baker SJ 1990 Enhanced testosterone secretion in adult rams after establishment of a high-frequency, low-amplitude pattern of LH pulses in the nonbreeding season occurs without changes in the number or binding affinity of testicular LH receptors. Acta Endocrinologica (Copenhagen) 122 55-61.

Sanford LM \& Dickson KA 2008 Prolactin regulation of testicular development and sexual behavior in yearling Suffolk rams. Small Ruminant Research 77 1-10.

Sanford LM \& Ponzilius K-H 1989 The pattern of LH release in the adult ram influences the testicular steroidogenic response to individual $\mathrm{LH}$ pulses and is regulated by testosterone negative feedback. Journal of Andrology $101-7$.

Sanford LM \& Robaire B 1990 Interaction of season and estradiol in the regulation of gonadotropin secretion in the ram. Canadian Journal of Physiology and Pharmacology 68 150-156.

Sanford LM, Beaton DB, Howland BE \& Palmer WM 1978 Photoperiodinduced changes in $\mathrm{LH}, \mathrm{FSH}$, prolactin and testosterone secretion in the ram. Canadian Journal of Animal Science 58 123-128.

Sanford LM, VogImayr JK, Vale WW \& Robaire B 1993 Photoperiodmediated increases in serum concentrations of inhibin, folliclestimulating hormone, and luteinizing hormone are accentuated in adult shortened-scrotum rams without corresponding decreases in testosterone and estradiol. Biology of Reproduction 49 365-373.
Sanford LM, Price CA, Leggee DG, Baker SJ \& Yarney TA 2002 Role of FSH, numbers of $\mathrm{FSH}$ receptors and testosterone in the regulation of inhibin secretion during the seasonal testicular cycle of adult rams. Reproduction $123269-280$

SAS 1989 SAS/STAT User's Guide Version 6, Fourth Edition, Cary NC: Statistical Analysis System Institute Inc.

Schanbacher BD, Pelletier J \& Hochereau-de-Reviers MT 1987 Follicle stimulating hormone, luteinizing hormone and testicular Leydig cell responses to estradiol immunization in Ile-de-France rams. Journal of Andrology 8 97-102.

Takase M, Tsutsui K \& Kawashima S 1990 Effects of prolactin and bromocryptine on the regulation of testicular luteinizing hormone receptors in mice. Journal of Experimental Zoology 256 200-209.

Tortonese DJ, Brooks J, Ingleton P, McNeilly JR \& McNeilly AS 1996 Prolactin receptor gene expression and specific translation of the signal in the ovine anterior hypothalamus and pituitary gonadotrophs. Proceedings of the 10th International Congress of Endocrinology, San Francisco, CA, p 303 (Abstract P1-673).

Tortonese DJ, Brooks J, Ingleton PM \& McNeilly AS 1998 Detection of prolactin receptor gene expression in the sheep pituitary gland and visualization of the specific translation of the signal in gonadotrophs. Endocrinology 139 5215-5223.

Voogt JL, de Greef WJ, Visser TJ, de Koning J, Vreeburg JT \& Weber RF 1987 In vivo release of dopamine, luteinizing hormone-releasing hormone and thyrotropin-releasing hormone in male rats bearing a prolactin-secreting tumor. Neuroendocrinology 46 110-116.

Weiss-Messer E, Ber R \& Barkey RJ 1996 Prolactin and MA-10 Leydig cell steroidogenesis: biphasic effects of prolactin and signal transduction. Endocrinology 137 5509-5518.

Wilson PR \& Lapwood KR 1978 Studies of hormone secretion in Romney rams: luteinizing hormone, testosterone and prolactin plasma profiles, $\mathrm{LH}$ /testosterone interrelationships and the influence of seasons. Theriogenology 9 279-294.

Yarney TA, Sanford LM \& Sairam MR 1988 Sheep testicular gonadotropin binding sites: characterization and changes with surgical shortening of the scrotum. Canadian Journal of Physiology and Pharmacology 66 1319-1327.

Received 30 April 2009

First decision 12 June 2009

Revised manuscript received 16 August 2009

Accepted 14 September 2009 